\title{
Seasonal Diversity of Rhizospheric Microfungi in Two Different Age Group of Tea Plantation in Tripura, Northeast India
}

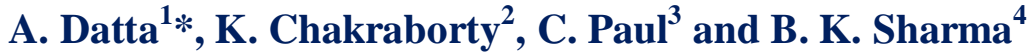 \\ ${ }^{1}$ Department of Botany, Govt. Degree College Dharmanagar, Dharmanagar-799253, \\ Tripura, India \\ ${ }^{2}$ Department of Botany, Tripura University, Suryamaninagar-799022, Tripura, India \\ ${ }^{3}$ Department of Forestry and Biodiversity, Tripura University, Suryamaninagar-799022, \\ Tripura, India \\ ${ }^{4}$ Department of Microbiology, Tripura University, Suryamaninagar-799022, Tripura, India \\ *Corresponding author e mail: abhijitdgc77@gmail.com
}

\begin{abstract}
A B S T R A C T
\section{Keywords}

Tea plantation, Soil microfungi,

Seasonal diversity, Soil physiochemical properties.

\section{Article Info}

Accepted:

15 February 2016 Available Online: 10, March 2016

Seasonal diversity of rhizospheric microfungi associated with two different age group of tea plantation was examined by using serial dilution and soil plate methods on the Czapek's Dox Agar medium supplemented with antibiotic Streptomycin. Identification and characterization of soil microfungi were done with the help of accessible manuals of fungi. Soil physico-chemical properties including soil $\mathrm{pH}$, electrical conductivity, moisture content, water holding capacity, bulk density, soil texture, organic carbon, organic matter, nitrogen, potassium and phosphorus content were also analyzed. A total of 32 fungal species and white sterile hyphae were isolated and identified from both the selected plantation sites. Among the identified fungal species, 2 species are belonging to the genus Alternaria, Fusarium and Rhizophus, 6 species belong to Aspergillus, 4 species belong to the genus Penicillium while 3 species are belong to the genus Verticillium. Only one species from each of the genus Bispora, Botrytis, Candida, Cephalosporium, Cladosporium, Culvularia, Dendropsis, Giocladium, Giotrichum, Helminthosporium, Humicola, Nigrospora and Trichoderma were also isolated and identified during the course of the work. Sterile hyphae were highly isolated from both the plantation sites. Aspergillus niger, Humicola brevis and Verticillium effusum were isolated throughout the year. The dominant genera in both the selected plantation were Aspergillus and Penicillium.
\end{abstract}

\section{Introduction}

Soil is a most precious natural resource that contains most diverse assemblages of living organisms (Swer et al., 2011) and the distribution of such organisms is influenced by the abundance and nature of the soil organic content, soil texture, surface vegetation as well as by other soil and climatic conditions (Waksman, 1944; Marschner et al., 2003). Rhizosphere is considered as a hotspot of microbial activities (Brimecomb et al., 2007). Fungi are fundamental for soil ecosystem 
functioning (Warcup, 1951) as they contribute appreciably in the recycling of nutrients in natural and modified ecosystems (Gadd, 2004). It was estimated that 1.5 million fungal species are present in natural ecosystems, but only $5-10 \%$ has been described formally (Hawksworth, 2001). Soil and rhizospheric fungal diversity is much higher than it was formerly thought (Vandenkoornhuyse et al., 2002; Gams, 2007). Frequent studies on soil fungi has gradually grown up the perception that soil fungal flora may vary depends on its native soils (Shi et al., 2002; Gleason et al., 2004; Burges, 1939). The relative abundance of individual species has been considered as measures of functional activities of the group in the particular habitat (Kjøller and Struwe, 1982, 1987).

In this connection the present investigation was carried out to enumerate the rhizospheric microfungal diversity and the percentage of relative abundance along with certain soil physicochemical properties of the rhizospheric soil collected from two different age group of tea plantation of Tripura, northeast India.

\section{Materials and Methods}

\section{Collection of the Soil Sample}

The rhizospheric soil samples were regularly collected from Ganganagar tea estate where both the desired i.e., 5 and 20 year old plantations are found during the period January-December, 2013. The age of both the plantation were confirmed by discussing with the labour of the tea estate. The five year old plantation was considered as a young plantation where as twenty years old plantation is considered as mature plantation. At first the sampling area was cleaned by removing dry leaves and other unwanted materials. Samples were collected from $10 \mathrm{~cm}$ below the soil surface by digging it and measured by using proper centimeter scale. The soil samples were mixed well after the collection of the samples from the rhizosphere of the desired plantation. The soil sample were collected in sterilized polythene bags and brought into the laboratory for further analysis.

\section{Soil Analysis}

For $\mathrm{pH}$ and electrical conductivity, $10 \mathrm{~g}$ of soil was dissolved in $50 \mathrm{ml}$ of distilled water and stirred for $20 \mathrm{~min}$. This solution was kept overnight and then the soil $\mathrm{pH}$ and electrical conductivity was measured using a digital $\mathrm{pH}$ and conductivity meter respectively. Moisture content of the soil sample was determined by following the method of (Jackson, 1967). Soil texture was determined by Boyoucous hydrometric method given by Allen et al. (1974). Water holding capacity was determined following the method outlined by Allen et al. (1974). Bulk density of the soil sample was determined by (Anderson and Ingram, 1993) method. The Organic Carbon was determined by using Walkley-Black (1934) method.

The soil available Nitrogen was estimated following Black (1982) method. Available Phosphorus and Potassium of soil were determined using the method of Jackson (1978). The percentage of the organic matter present in the soil sample were determined by following the formula Percentage of organic matter=Percent of carbon $\times 1.724$.The factor $1 \quad .724$ is based on the assumption that the carbon is only $58 \%$ of organic matter.

\section{Preparation of Media and Inoculation}

The soil micro fungi were enumerated by Serial dilution (Waksman, 1927) and soil 
plate method (Warcup, 1950). The culture media used for the isolation of the soil micro fungi was Czapek's Dox agar. The desired glass wares and the prepared media were sterilized in the autoclave and transferred to the laminar air flow. Then One percent antibiotic (Streptomycin) was added in all the petridishes for preventing them from the contamination of bacteria.

The media is then poured in the petri plates and allowed to cool at room temperature. After inoculation, the plates were kept for minimum incubation for 4-6 days at $25^{\circ} \mathrm{C}$ until the colonies grow well in dust free chamber. Isolates which did not produce spores were treated as sterile mycelium (Lacap et al., 2003).

\section{Lacto Phenol Cotton Blue Mounting}

A portion of the mycelium of the representative colonies was picked up with the help of a pair of needles and grease free semi permanent slides were prepared using Lacto phenol cotton blue. The slide was gently heated in a spirit lamp to release the air bubbles, if any present inside the cover glass. The excess stain was removed using tissue paper and observed under microscope for the identification of the fungus.

\section{Identification of Fungi}

The fungal species were identified on the basis of cultural characteristics and morphology of fruiting bodies and spores by using standard texts and keys. The species was then identified by using the identification manual (Gilman, 1957; Barnett and Hunter, 1972).

\section{Data Analysis}

All the calculation was done in Microsoft Excel, 2007. Percentage of relative abundance of the fungal species was calculated using the following formula

$$
\begin{gathered}
\begin{array}{r}
\text { Total no of colonies of a particular } \\
\text { genus } / \text { species }
\end{array} \\
\% \text { of relative abundance }=----------------X 100 \\
\text { Total no of colonies of all the } \\
\text { genera } / \text { species }
\end{gathered}
$$

\section{Results and Discussion}

\section{Soil Physicochemical Properties}

The $\mathrm{pH}$ of the rhizospheric soil sample of both the selected tea plantation sites was found to be acidic and soil of the mature plantation is slightly more acidic than the young plantation. Moisture content, Water holding capacity and bulk density was higher in 20 year tea plantation than 5 year old plantation. The clay content of both the soil sample of selected plantation is almost similar where as the slit content of the 5 year old plantation is higher than the 20 year old plantation. Sand content is high in 20 year old plantation than that of 5 year old plantation. Organic carbon, nitrogen, phosphorus, potassium and organic matter content are found to be higher in 20 year old plantation in comparison with the 5 year old tea plantation.

\section{Rhizospheric Microfungi}

In this present investigation, a total of 32 fungal species and white sterile hyphae were isolated and identified from both the selected plantation sites. Among the identified fungal species 2 species are belonging to the genus Alternaria, Fusarium and Rhizophus, 6 species belong to Aspergillus, 4 species belong to Penicillium while 3 species are belong to the genus Verticillium. Only one species of each of the genus Bispora, Botrytis, Candida, Cephalosporium, Cladosporium, Culvularia, Dendropsis, Giocladium, Giotrichum, Helminthosporium, Humicola, Nigrospora 
and Trichoderma were also isolated and identified during the course of the work. Sterile hyphae were highly isolated from both the plantation sites. This present study revealed that Aspergillus niger, Humicola brevis and Verticillium effusum were isolated throughout the year. The dominant genera in both the selected plantation were Aspergillus and Penicillium.In winter, Penicillium restrictum has the highest percentage of relative abundance and Aspergillus flavus has the lowest percentage of relative abundance in 5 year old plantation where as Rhizophus nigricans and Culvularia geniculatum exhibited the highest and lowest percentage of relative abundance respectively in 20 year old tea plantation. In Pre monsoon Aspergillus niger has the highest percentage of relative abundance and Alternaria tennius has the lowest percentage of relative abundance in 5 year as well as 20 year old tea plantation. During monsoon Verticillium effusum and Aspergillus niger has the highest percentage of relative abundance where as Culvularia geniculatum has the lowest percentage of relative abundance in 5 year old plantaion. Aspergillus niger and Giotrichum sp have the highest and lowest percentage of relative abundance respectively in 20 year old plantation in monsoon. In Retreating
Monsoon, Aspergillus niger has the highest percentage of relative abundance and Aspergillus candidus and Verticillium effusum has the lowest percentage of relative abundance in 5 year old plantation where as Aspergillus niger exhibited the highest percentage of relative abundance in 20 year old tea plantation.

Chaudhary and Sachar (1934), Trenser et al.(1954), Saksena (1955), Miller et al. (1957) and Saksena and Sarbhoy (1964),Rama rao (1969) and Persiani et al. (1998) have been reported that soil mycoflora and fungal population of a particular soil significantly differ from season to season. Dkhar and Mishra (1987) revealed that the variations in fungal diversity in some soil types were due to changes in soil organic contents, $\mathrm{pH}$, water holding capacity and temperature of respective season. According to Bhat and Kaveriappa, 2011; Gomathi et al., 2011; Shiny et al., 2013; Gopal \& Kurien, 2013 species of the genus Aspergillus and Penicillium were dominant in soil that revealed the similarity with our present findings. The ability of Aspergillus species to produce toxins and antibiotics produced by Penicillium species may be helpful in inhibiting the growth of other fungal species.

Table.1 Soil Physico-Chemical Properties of the Rhizospheric Soil Samples Collected from the Rhizosphere of Five and Twenty Year Old Tea Plantations

\begin{tabular}{|c|c|c|c|c|c|c|c|c|c|c|c|c|c|}
\hline $\begin{array}{l}\text { Age } \\
\text { (Years) }\end{array}$ & $\mathrm{pH}$ & $\begin{array}{l}\text { E.C. } \\
(\mathrm{cScm}-1)\end{array}$ & $\begin{array}{l}\text { M.C. } \\
(\%)\end{array}$ & $\begin{array}{l}\text { W.H. } \\
\text { C. } \\
(\%)\end{array}$ & $\begin{array}{l}\text { B.D. } \\
\left(\mathrm{g} / \mathrm{cm}^{3}\right)\end{array}$ & $\begin{array}{l}\text { Clay } \\
(\%)\end{array}$ & $\begin{array}{l}\text { Slit } \\
(\%)\end{array}$ & $\begin{array}{l}\text { Sand } \\
(\%)\end{array}$ & $\begin{array}{l}\text { O.C. } \\
(\%)\end{array}$ & $\begin{array}{l}\mathrm{N} \\
(\mathrm{ppm})\end{array}$ & $\begin{array}{l}P \\
\text { (pp } \\
\mathrm{m})\end{array}$ & $\begin{array}{l}\mathrm{K} \\
(\mathrm{ppm})\end{array}$ & $\begin{array}{l}\text { O. } \\
\text { M. }\end{array}$ \\
\hline 5 & $\begin{array}{l}4.56 \pm \\
0.012\end{array}$ & $\begin{array}{l}112 \pm \\
0.33\end{array}$ & $\begin{array}{l}20.5 \\
\pm 0.0 \\
6\end{array}$ & $\begin{array}{l}47.02 \\
\pm 7.67\end{array}$ & $\begin{array}{l}1.28 \pm \\
0.09\end{array}$ & $\begin{array}{l}11 \pm \\
1.56\end{array}$ & $\begin{array}{l}23 \pm \\
0.71\end{array}$ & $\begin{array}{l}66 \pm \\
2.81\end{array}$ & $\begin{array}{l}1.49 \\
\pm 0.2 \\
8\end{array}$ & $\begin{array}{l}58.12 \\
\pm 2.52\end{array}$ & $\begin{array}{l}10.1 \\
1 \pm 0 . \\
49\end{array}$ & $\begin{array}{l}41.8 \pm \\
0.21\end{array}$ & $\begin{array}{l}2.56 \\
\pm \\
0.96\end{array}$ \\
\hline 20 & $\begin{array}{l}4.51 \pm \\
0.003\end{array}$ & $\begin{array}{l}117 \pm \\
0.51\end{array}$ & $\begin{array}{r}29.5 \\
\pm .03\end{array}$ & $\begin{array}{l}50.11 \\
\pm 5.93\end{array}$ & $\begin{array}{l}1.29 \pm \\
0.15\end{array}$ & $\begin{array}{l}12 \pm \\
1.32\end{array}$ & $\begin{array}{l}19 \pm \\
0.87\end{array}$ & $\begin{array}{l}69 \pm \\
2.73\end{array}$ & $\begin{array}{l}1.54 \\
\pm \\
0.03\end{array}$ & $\begin{array}{l}66 \pm \\
2.36\end{array}$ & $\begin{array}{l}13.0 \\
1 \pm 1 \\
21\end{array}$ & $\begin{array}{l}47.88 \\
\pm 0.26\end{array}$ & $\begin{array}{l}2.65 \\
\pm \\
0.84\end{array}$ \\
\hline
\end{tabular}


Table.2 Showing Seasonal Percentage of Relative Abundance of Rhizospheric Microfungi Associated with Two Different Age Group of Tea Plantations

\begin{tabular}{|c|c|c|c|c|c|c|c|c|}
\hline \multirow[t]{2}{*}{ Fungal flora } & \multicolumn{2}{|c|}{ Winter } & \multicolumn{2}{|c|}{ Pre monsoon } & \multicolumn{2}{|c|}{ Monsoon } & \multicolumn{2}{|c|}{$\begin{array}{l}\text { Retreating } \\
\text { Monsoon }\end{array}$} \\
\hline & $\begin{array}{l}5 \\
\text { Years }\end{array}$ & $\begin{array}{l}20 \\
\text { Years }\end{array}$ & $\begin{array}{l}5 \\
\text { Years }\end{array}$ & $\begin{array}{l}20 \\
\text { Years }\end{array}$ & $\begin{array}{l}5 \\
\text { Years }\end{array}$ & $\begin{array}{l}20 \\
\text { Years }\end{array}$ & $\begin{array}{l}5 \\
\text { Years }\end{array}$ & $\begin{array}{l}20 \\
\text { Years }\end{array}$ \\
\hline Alternaria alternata & - & - & 6.45 & - & - & - & - & - \\
\hline Alternaria tennius & - & - & 2.85 & 2.70 & - & - & - & - \\
\hline Aspergillus candidus & - & - & - & 8.75 & 6.60 & 8.50 & 2.77 & 6.81 \\
\hline Aspergillus clavatus & - & - & 7.14 & 5.59 & 6.25 & - & 11.11 & 9.09 \\
\hline Aspergillus flavus & 4.0 & - & - & - & 10.34 & 12.50 & 5.55 & - \\
\hline Aspergillus fumigatus & - & - & 17.07 & 5.26 & 11.53 & 10.34 & - & 2.27 \\
\hline Aspergillus niger & 8.00 & 10.52 & 16.48 & 16.45 & 15.38 & 22.80 & 16.66 & 18.18 \\
\hline Aspergillus vessicolor & 16.66 & 5.6 & - & - & - & - & - & 2.27 \\
\hline Bispora sp & - & - & 5.71 & 10.69 & 6.25 & 5.26 & - & 2.27 \\
\hline Botrytis sp & - & - & 6.06 & 5.48 & - & - & - & - \\
\hline Candida ablicans & - & 6.45 & 4.39 & - & - & - & - & - \\
\hline $\begin{array}{l}\text { Cephalosporium } \\
\text { ceremoiodes }\end{array}$ & - & - & 5.77 & 7.31 & 9.37 & 8.50 & 11.11 & 2.27 \\
\hline Cladosporium herbarum & - & - & 9.01 & 5.71 & 11.53 & 17.24 & 13.88 & 13.63 \\
\hline Culvularia geniculatum & - & 3.22 & 9.04 & 8.57 & 3.12 & 7.89 & - & - \\
\hline Dendropsis sp & - & - & 3.03 & - & - & - & - & - \\
\hline Fusarium oxysporium & - & - & 2.85 & 5.26 & 9.37 & - & 8.33 & 11.36 \\
\hline Fusarium poea & - & - & - & 7.89 & - & - & - & 2.27 \\
\hline Giocladium sp. & - & - & - & - & - & 8.33 & - & - \\
\hline Giotrichum sp. & - & - & - & - & - & 3.12 & - & - \\
\hline Helminthosporium oryzae & - & - & 12.12 & 14.28 & 12.50 & 2.77 & 2.77 & - \\
\hline Humicola brevis & 8.02 & 10.03 & 6.06 & 8.57 & 6.60 & 6.25 & 8.33 & 2.27 \\
\hline Nigrospora sp & - & - & 3.03 & 2.85 & - & - & - & - \\
\hline Penicillum citrinum & 5.33 & 6.45 & & & - & - & - & - \\
\hline Penicillium granulatum & 9.9 & 13.33 & 9.37 & 5.55 & - & - & - & 6.81 \\
\hline Penicillium restrictum & 26.13 & 5.96 & & & - & - & - & - \\
\hline Penicillium viridicatum & - & - & 6.06 & 5.40 & - & - & 11.11 & - \\
\hline Rhizopus nigricans & 6.16 & 15.36 & 6.06 & 2.85 & 7.69 & 10.74 & 5.55 & - \\
\hline Rhizopus sp & - & - & - & - & 6.60 & 5.70 & - & 4.54 \\
\hline Trichoderma lignorum & 19.85 & 13.14 & - & - & 10.00 & 6.25 & - & 6.81 \\
\hline Verticillium candilabrum & - & - & - & - & 10.00 & 8.50 & - & - \\
\hline Verticillium effusum & 6.00 & 6.45 & 12.12 & 8.57 & 15.38 & 10.34 & 2.77 & 4.54 \\
\hline Verticillium glaucam & 9.09 & 13.33 & 6.25 & 10.81 & 3.84 & 3.14 & - & 2.27 \\
\hline White sterile hyphae & 12.2 & 9.49 & 8.57 & 7.19 & 7.69 & 6.89 & 3.22 & 5.26 \\
\hline
\end{tabular}


Figure.1 Graphical Representation of the Rhizospheric Soil Physiochemical Properties of Two Different Age Group Tea Plantations

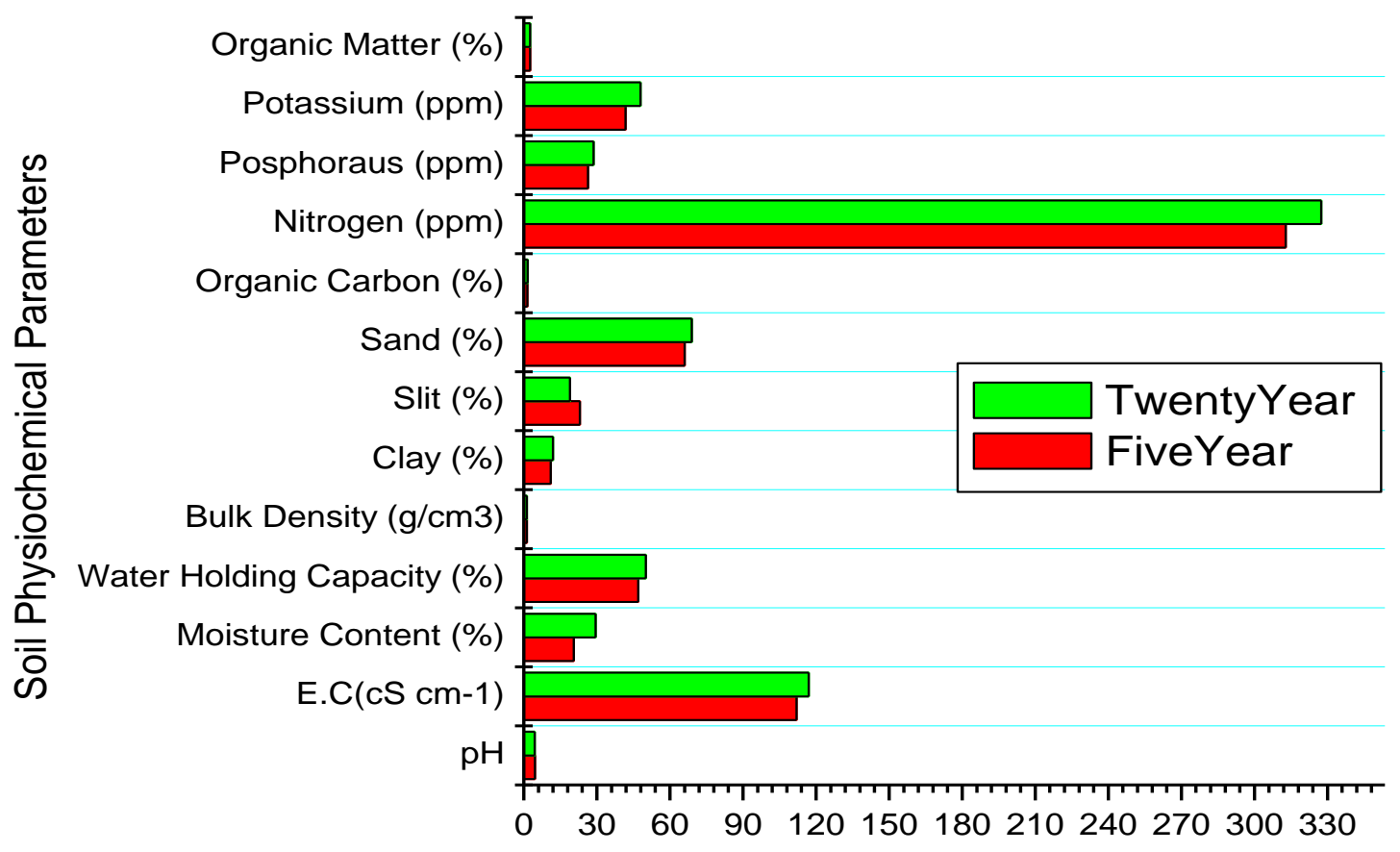

Figure.2 Graphical Representation of Relative Abundance (\%) of Fungal Species Isolated from Two Different Age Group of Tea Plantations During Winter Season

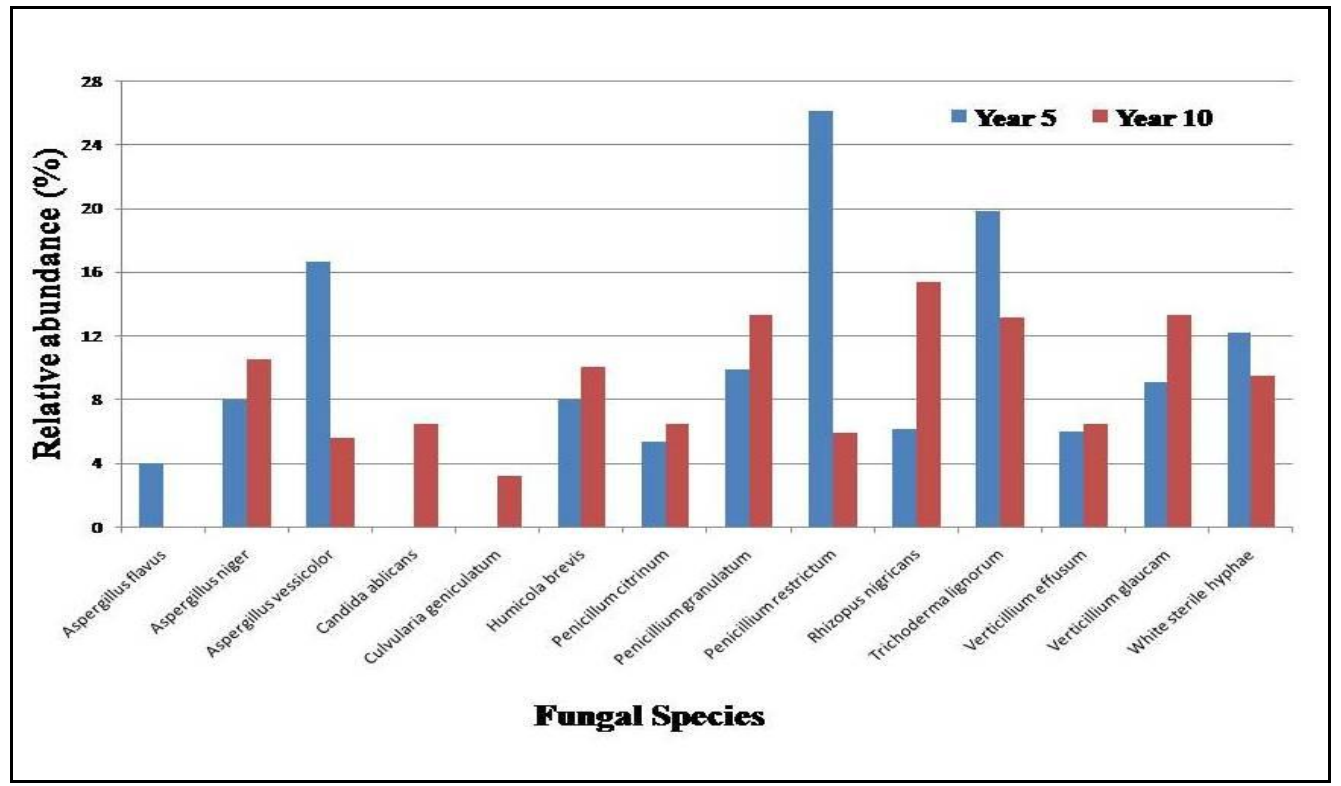


Figure.3 Graphical Representation of Relative Abundance (\%) of Fungal Species Isolated from Two Different Age Group of Tea Plantation During Premonsoon Season

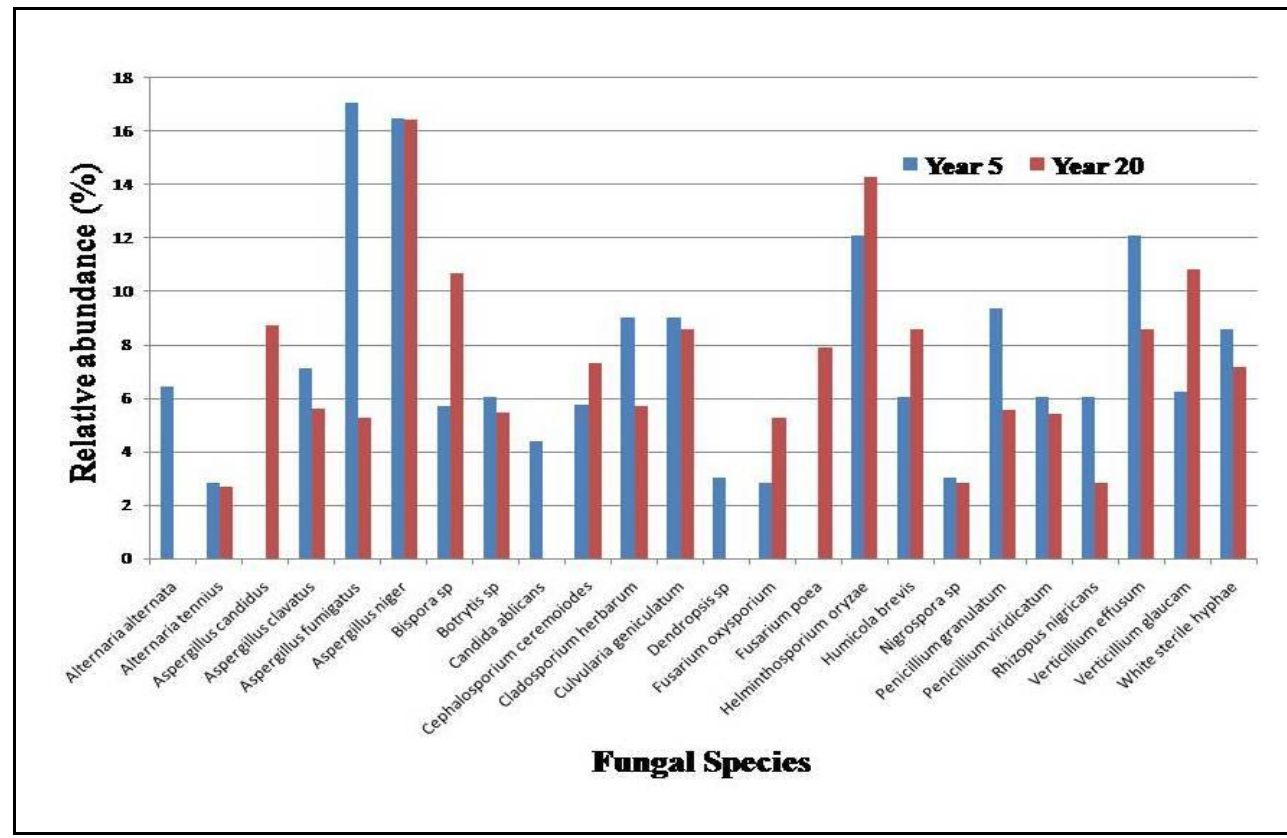

Figure.4 Graphical Representation of Relative Abundance (\%) of Fungal Species Isolated from Two Different Age Group of Tea Plantation During Monsoon Season

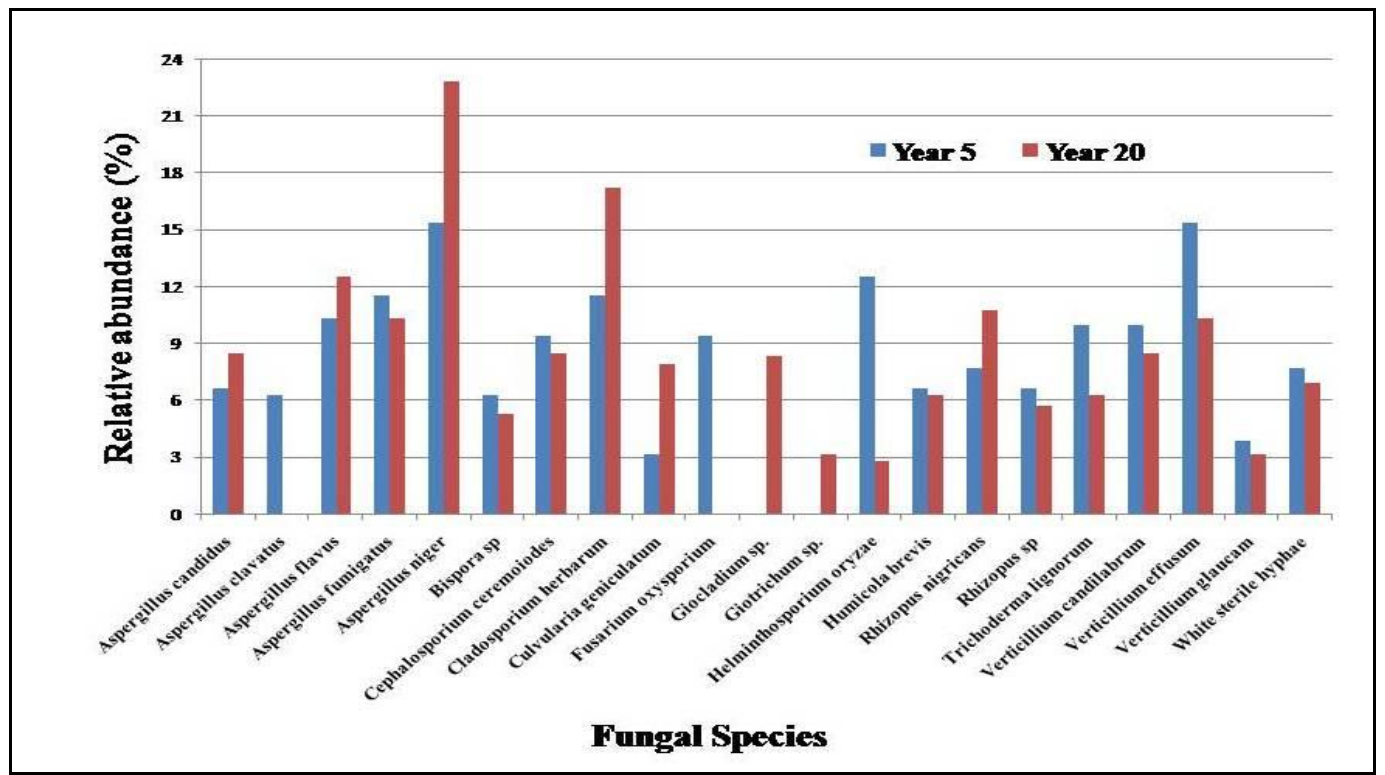


Figure.5 Graphical Representation of Relative Abundance (\%) of Fungal Species Isolated from Two Different Age Group of Tea Plantation During Retreating Monsoon Season

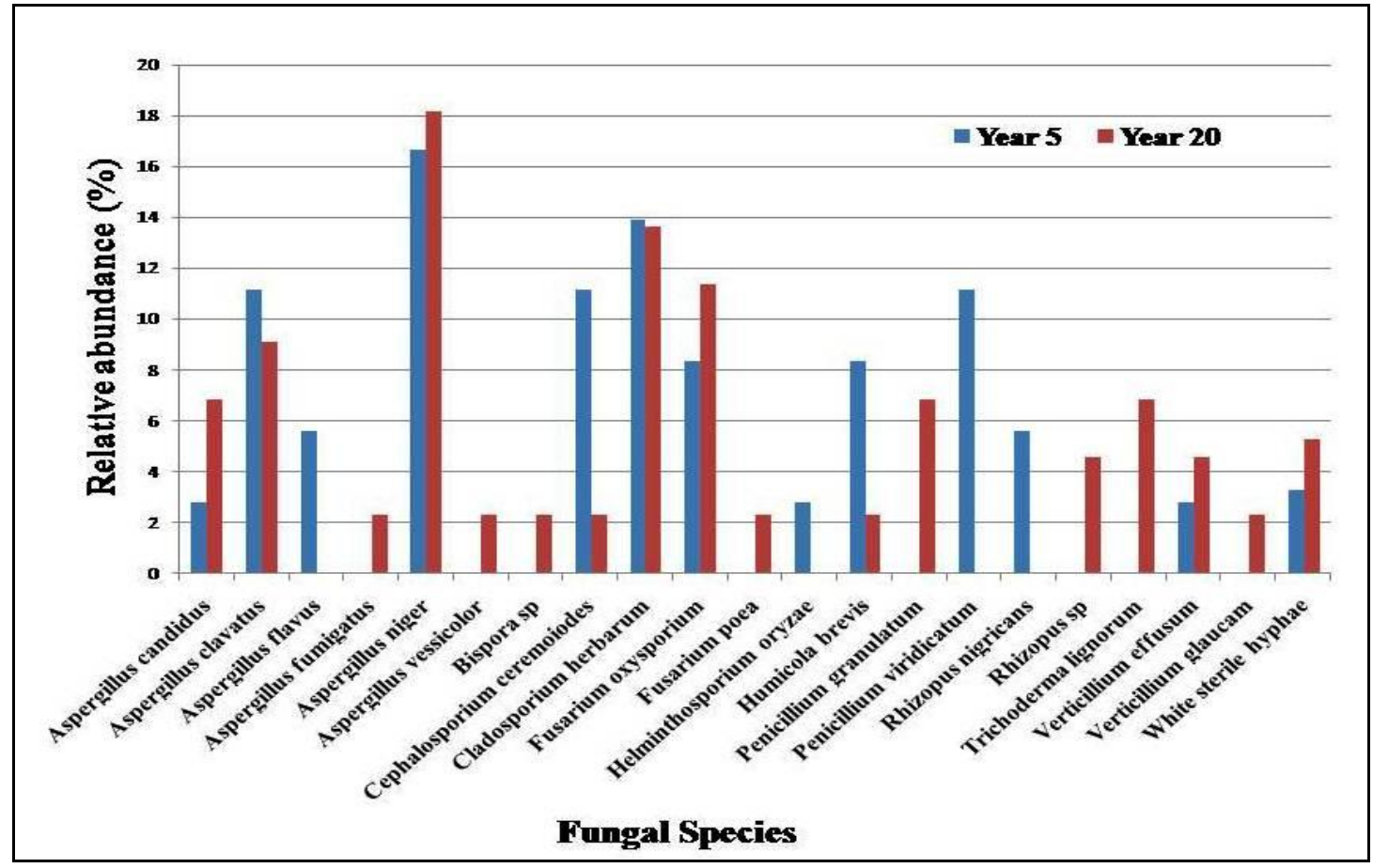

In conclusion, the present investigation provides valuable information about the seasonal rhizosphere fungal diversity of two different age group of tea plantation. A total of 32 fungal species and white sterile hyphae were isolated and identified from both the selected plantation sites during the course of the investigation. Among the isolated rhizospheric microfungi Aspergillus niger, Humicola brevis and Verticillium effusum were isolated throughout the year indicating that the nutrient content and the environment of both the selected plantation sites are suitable for the growth of the said fungal isolates. The most dominant fungal isolates are belonging to the genus Aspergillus and Penicillium However; the present study has some limitation as the sampling of rhizospheric soil was confined only to selected experimental plots. There is need for a wider study area for the complete representation of the seasonal fungal diversity associated with the tea plantation.

\section{Acknowledgement}

We owe our special thanks to HOD, Department of Botany Govt. Degree College Dharmanagar for providing laboratory facilities to complete our research work.

\section{References}

Allen, S.E., Grimshaw, H.M., Parkinson, J.A., Quarmby, C. 1974. Chemical analysis of ecological materials, John Wiley and Sons, New York.

Anderson, J.M., Ingram, J.S.I. 1993. Tropical soil biology and fertility: a handbook of methods. C.A.B. International, UK.

Barnett, H.L., Hunter, B.B. 1972. Illustrated Genera of Imperfect Fungi,(3rd edition). Burgess Publishing Company, Minneapolis. p. 331.

Bhat, P.R., Kaveriappa, K.M. 2011. Rhizoplane mycoflora of some 
species of Myristicaceae of the Western Ghats, India. Tropical Ecol., 52(2): 163-175.

Black, C.A. 1982. Methods of soil analysis. Pregmon Press, England.

Brimecombe, M.J., De Leij, F.A.A.M., Lynch, J.M. 2007. Rhizodeposition and microbial populations. In: Pinton R., Veranini Z. \& Nannipieri P., eds. The rhizosphere biochemistry and organic substances at the soil-plant interface. New York, USA.

Burges, A. 1939. Soil fungi and root infection. Broteria, Serie deCiencias Naturais.

Chaudhary, H., Sachar, G.S. 1934. A study of fungus flora of Punjabsoils. Annales of Mycol., 32: 90-110.

Dkhar, M.S., Mishra, R.R. 1987. Microbial population, fungal biomass and $\mathrm{CO} 2$ evolution in maize (Zea mays field soils). Pl. Soil, 99: 277-203.

Gadd, G.M. 2004. Mycotransformation of organic and inorganic substrates. Mycologist, 18: 60-70.

Gams, W. 2007. Biodiversity of soilinhabiting fungi. Biodiversity and Conservation, 16: 69-72.

Gilman, J.C. 1957. A manual of soil fungi. 2nd ed. Iowa, The Iowa State College Press, pp. 450.

Gleason, F.H., Letcher, P.M., McGee, P.A. 2004. Some Chytridiomycota in soil recover from drying and high temperatures. Mycol. Res., 108: 583589.

Gomathi, S., Ambikapathy, V., Panneerselvam, A. 2011. Studies on Soil Mycoflora in Chilli Field of Thiruvarur District. Asian J. Res. Pharm. Sci., 1(4): 117-122.

Hawksworth, D.L. 2001. The magnitude of fungal diversity: the 1.5 million species estimate revisited. Mycol. Res., 105: 1422-1432.
Jackson, M.L. 1978. Soil chemical analysis. Prentice Hall, New Delhi, India.

Jackson, M.L. 1967. Soil Chemical analysis. Prentice Hall, New Delhi, India.

Kjøller, A., Struwe, S. 1987. Functional groups of microfungi on decomposing ash litter. Pedobiologia, 30: 151-159.

Kjøller, A., Struwe, S. 1982. Microfungi in ecosystems: fungal occurrenceand activity in litter and soil. Oikos, 39: 389-422.

Lacap, D.C., Hyde, K.D., Liew, E.C.Y. 2003. An evaluation of the fungal "morph type" concepts based on ribosomal DNA sequence. Fungal Diversity, 12: 53-66.

Marschner, P., Kandeler, E., Marschner, B. 2003. Structure and function of the soil microbial community in a longterm fertilizer experiment. Soil Biol. Biochemistry, 35: 453-461.

Miller, J.H., Giddins, J.E., Foster, A.A. 1957. A survey of fungi of forest and cultivated soils of Georgia. Mycol., 49: 779-808.

Rama Rao, P. 1969. Studies on soil fungi III, seasonal variation anddistribution of microfungi in some soils of Andhra Pradesh. Trans. British Mycol. Soc., 52(2): 277-298.

Saksena, R.K., Sarbhoy, A.K. 1964. Ecology of the soil fungi of UttarPradesh - I. proceedings National Institute Science. India, 29: 207-224.

Saksena, S.B. 1955. Ecological factor governing the distribution of soil microfungi, J. Ind. Botanical Soc., 34(3): 262-298.

Saksena, R.K., Sarbhoy, A.K. 1964. Ecology of the soil fungi of UttarPradesh - I. Proceedings National Institute Science. India. 29: 207-224.

Shi, L, Guttenberger, M., Kottke, I., Hampp, 
R. 2002. The effect of droughton mycorrhizas of beech (Fagus sylvatica L.) changes in communitystructure and the content of carbohydrates and nitrogen storagebodies of the fungi. Mycorrhiza, 12: 303-311.

Shiny, N.P., Gaddeyya, G., Ratna Kumar, P.K. 2013. An investigation on soil mycoflora of different crop fields at Narasannapeta Mandal, Srikakulam District. Int. Res. J. Environment Sci., 2(9): 38-44.

Surendra, K. G., Kurien, S. 2013. Fungal diversity in the rhizosphere of tropical homestead and plantation crops of kerala. Int. J. Agri. Environment Biotechnol., 6(2): 249253.

Swer, H., Dkhar, M.S., Kayang, H. 2011. Fungal population and diversity in organically amended agricultural soils of Meghalaya, India. J. Organic Systems, 6: 1177-4258.

Tresner, H.D., Bakus, M.P., Curtis, J.T. 1954. Soil microfungi in relation to hardwood forest continum in southern Wiskinson. Mycol., 46: 314-333.

Vandenkoornhuyse, P., Baldauf, S.L., Leyval, C., Straczek, J., Young, J.P. 2002. Extensive fungal diversity in plant roots. Science, 295: 2051.

Waksman, S.A. 1927. Principles of soil microbiology, Williams and Wilkins Co., Baltimore.

Waksman, S.A. 1944. Three decades with soil fungi. Soil Sci., 58: 89-114.

Walkley, A., Black, I.A. 1934. An examination of Degtjareff method for determining soil organic matter and a proposed modification of the chromic acid titration method. Soil Sci., 37: 29-37.

Warcup, J.H., 1950. The soil plate method for isolation of fungi from soil, London. Nature, 166: 117- 118.

Warcup, J.H. 1951. The ecology of soil fungi. Trans. Brit. Mycol. Soc., 34: 376-399.

\section{How to cite this article:}

Datta, A., Chakraborty, K., Paul, C. and Sharma, B. K. 2016. Seasonal Diversity of Rhizospheric Microfungi in Two Different Age Group of Tea Plantation in Tripura, Northeast India. Int.J.Curr.Microbiol.App.Sci. 5(3): 363-372.

doi: http://dx.doi.org/10.20546/ijcmas.2016.503.043 